\title{
Other Eye Color
}

National Cancer Institute

\section{Source}

National Cancer Institute. Other Eye Color. NCI Thesaurus. Code C160244.

The color of the eye was identified in the study but is not present in the form. 